\title{
Analysis of Disaster Vulnerability Capacity in Mempawah Hilir Subdistricts
}

\author{
Nunik Hasriyanti ${ }^{1}$, Andi Zulestari ${ }^{2}$, Ismail Ruslan ${ }^{3}$ and Lestari Agustrihardaning $^{4}$ \\ ${ }^{1}$ Urban Design Department, State Polytechnic of Pontianak, Indonesia \\ ${ }^{2}$ Architecture Department, State Polytechnic of Pontianak, Indonesia \\ ${ }^{3}$ FUAD Faculty, State Institute Islamic Religion of Pontianak, Indonesia \\ ${ }^{4}$ Provincial Disaster Management Agency, Province West Kalimantan \\ niexnoe@gmail.com
}

\begin{abstract}
Data in the West Kalimantan Figures (BPS) in 2010 [1], there were 34 sub-districts in the West Kalimantan coastal area with a total area of $20,066 \mathrm{Km} 2$ and a population of $1,100,000$ people or $25 \%$ of the projected total of 4.4 million residents of West Kalimantan. It means that people who live in coastal areas, including small islands, have become the majority concentration on the distribution of the population of West Kalimantan while having a close relationship with access to potential marine and coastal resources and environmental use. In the Strategic Plan of the West Kalimantan Regional Disaster Management Agency 2013-3018 [1] states that the inhibiting and driving factors are in disaster management in West Kalimantan due to the absence of hazard-prone mapping and safe disaster mapping, especially in coastal areas. The purpose of this research is to find out and analyze the level of disaster vulnerability in the District of Mempawah Hilir. The data collection method used is to determine the aspects and indicators of capacity assessment of disasters in the District of Mempawah Hilir. From the results of the assessment of factors A to factor E, it can be concluded that the level of capacity of each village in Mempawah District is still very low. This low capacity value is dominated in villages in Sungai Kunyit and Siantan Districts. Villages that have moderate capacity value are Kuala Secapah Village, Pasir Village, Sengkubang Village, and Jungkat Village. Overall, villages in Mempawah sub-district are still low on the early warning factor and disaster risk assessment and preparedness development factors on all lines.
\end{abstract}

(c) 2018 IJBESR. All rights reserved.

Keywords: disaster vulnerability, capacity analysis, urban mitigation

\section{Introduction}

Coastal areas are known as aquatic ecosystems that have enormous resource potential, which is an opportunity for increased productive economic activity. In general, the high potential risk of disasters in Indonesia's coastal areas is caused not only by geological and meteorological factors but also by environmental conditions and coastal ecosystems. Those conditions are because there is not well-maintained, low social independence, starting to fade local norms and culture in protecting the environment and low quality and quantity of necessary infrastructure, which leads to high levels of poverty in coastal areas [6] [7]. In the 20132018 West Kalimantan Regional Disaster Management Agency Strategic Plan [1], it is stated that the inhibiting and driving factors in disaster management in West Kalimantan are due to the absence of disaster-prone mapping and disaster safe mapping, especially in coastal areas. So that disaster early warning is not optimal delivered quickly to the community at the disaster location [2]. Please kindly read these notes carefully. One review that can be done to avoid this is through the 
use of spatial controls. Control of spatial use is one of the efforts to realize spatial order. Control of spatial use is an indispensable part of which cannot be separated from the spatial plan. In spatial use control activities, there is one thing that needs to be considered, namely regarding disaster risk. In this disaster risk analysis, it deals with threats and vulnerabilities [3]. This also happens in this case study with disaster risk conditions in coastal areas, especially in Mempawah Hilir District, Siantan District, and Sungai Kunyit District Mempawah District. This district consists of Kuala Secapah Village, Malikian Village, Penibung Village, Pasir Village, Sengkubang Village, Jungkat Village, Desa Outer Pin, Sungai Nipah Village, Wajok Hilir Village, Wajok Hulu Village, Semudun Village, Mendalok Village, Sungai Dungun Village, Sungai Limau Village, Sungai Kunyit Laut Village, Sungai Kunyit Dalam Village, Sungai Kunyit Hulu Village. Villages in Mempawah Hilir District, which geographically located directly adjacent to the South China Sea, have a direct impact in the event of a tidal wave due to rising sea levels.

The impact of climate change will be compounded by environmental, population, and poverty problems. Because the environment is damaged, nature will be more vulnerable to climate change [4]. An increase in sea level between 8 to 30 centimeters will also have a severe impact on coastal cities increasingly susceptible to flooding and storm runoff. Also, the development of activities, both settlements, industry, tourism, and other socioeconomic activities that are concentrated in the coastal region, allows the potential for significant regional dynamics in the coastal region. The high resources cause this in the coastal area, which will lead to potential conflicts of interest in the future, which will lead to economic and ecological losses if there is no proper management of the area. Like Brooks [11] present a set of indicators of vulnerability and capacity to adapt to climate variability, and by extension climate change, derived using a novel empirical analysis of data aggregated at the national level on a decadal timescale.

\section{Material and Methods}

Mitigation [8] is carried out following the level of risk and potential disasters in each location. Mitigation will include: Structural mitigation consists of prevention or mitigation of natural disasters by supervising building construction to be more resistant to hazards. Also, non-structural mitigation includes actions that prioritize limiting the use of vulnerable areas natural disasters using land use (zoning). Mitigation actions can be classified into 2 (two) parts, namely passive mitigation, and active mitigation. Preventive actions are classified as passive mitigation. The mitigation include: the formulation of legislation, making disaster-prone maps and mapping problems; making guidelines/standards/ procedures; making brochures/leaflets/posters;

research/assessment of disaster characteristics; assessment/analysis of disaster risk; $\mathrm{PB}$ internalization in the local content of education; the formation of organizations or disaster task force units; and the strengthening of social units in the community such as forums; PB mainstreaming in development planning. Meanwhile, preventive measures that are classified as active mitigation include the creation and placement of warning signs, hazards, prohibitions on entering disasterprone areas and so on, Supervision of the implementation of various regulations on spatial planning, building permits (IMB), and other regulations relating to disaster prevention, basic training in disaster management for apparatuses and the community, relocation of residents from disaster-prone areas to safer areas, public awareness-raising and awareness, planning of temporary shelter areas and evacuation routes in the event of a disaster, construction of 
structures to function to prevent, securing and reducing impacts caused by disasters, such as: dykes, dams, coastal erosion barriers, earthquake resistant buildings and the like [5].

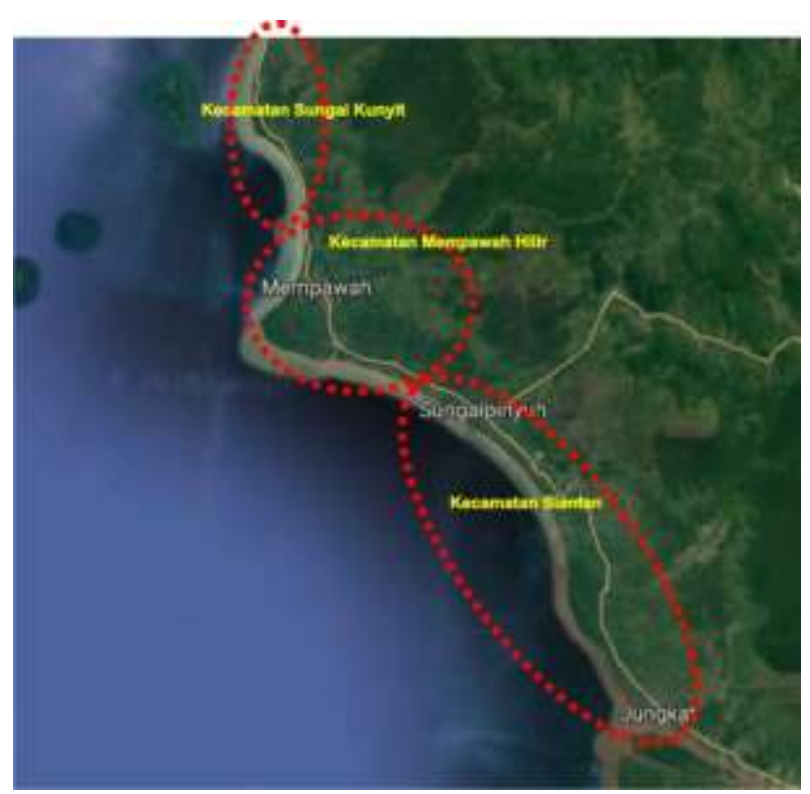

Figure 1: Delineation Map of Coastal Areas in Mempawah District, namely Siantan District, Sungai Kunyit District and Mempawah Hilir District

Source: Google Maps, 2019

According to Fuchs [12] that the concept of vulnerability is used today by various disciplines, and hence, it is embedded in multiple disciplinary theories underpinning either a technical or a social origin of the concept and resulting in a range of paradigms for either a qualitative or quantitative assessment of vulnerability. However, efforts to reduce the exposure to hazards and to create disaster-resilient communities require intersections among these theories, since human activity cannot be seen independently from the environmental settings and vice versa. Acknowledging different roots of disciplinary paradigms, methods determining structural, economic, institutional, or social vulnerability should be inter-woven to enhance our understanding of weakness and to adapt to ongoing global change processes. According to Spreiregen, it is stated that in principle, the purpose of urban design is to make cities more humane, linking the physical form of cities with natural conditions, harmonizing urban and nature, creating quality city spaces, and making cities a port of diversity. In addition, it is necessary to control spatial use because there are still mismatches and technical problems in the implementation of spatial planning. The mismatch of spatial use is due to the inconsistencies of regulations and the imbalance of spatial use control rules so that anticipatory measures are needed in the field. Control of spatial use can be done by providing incentives/disincentives and imposing sanctions on those who violate spatial use rules. The following is a map of the areas in Mempawah Hilir District, Sungai Kunyit District, and Siantan District that were affected by the disaster in the coastal region.

According to Rachmawati [9], disaster risk analysis that can be done for disaster-affected areas includes 3 (three) aspects of disaster risk, namely threats, vulnerability, and capacity. In this case, what will be analyzed at the three observation locations is the capacity aspect analysis. The capacity here is the overall strength, completeness, and resources of the community, social groups, or organizations that can be used to achieve agreed goals, including matters relating to disaster risk reduction. In Perka BNPB No. 2 of 2012, capacity is not assessed based on ownership of community assets but is evaluated based on the preparedness of an area by taking into account the existence of regulations to cope with disasters, the level of community knowledge of disasters, and early warning systems. Capacity assessment here is the potential of the community, individual, family, or community that makes them able to prevent, reduce, be prepared, and be able to recover immediately from an emergency disaster activity. This ability was assessed by a questionnaire to find out some capacity building factors including disaster 
management institutional arrangements at the city/village level, early warning, and disaster risk assessment at the village level; disaster education carried out by the village, efforts to reduce basic risk factors in the village, and village preparedness on all lines. The results of the assessment and recapitulation of the questionnaire are presented in tabular form and assessed for their capacity. Smit [10] reviews the concept of adaptation of human communities to global changes, especially climate change, in the context of adaptive capacity and vulnerability.

Birkmann [13] shows key linkages between the different concepts used within disaster risk management (DRM) and climate change adaptation (CCA) research. Further, it helps to illustrate the strong relationships between different concepts used in DRM and CCA. A framework is also a tool for communicating complexity and stresses the need for societal change to reduce risk and to promote adaptation.

The method used in this study is a qualitative method through the distribution of questionnaires in 3 sub-districts in Mempawah district, which are distributed in 17 villages in the sub-district. From the results of the questionnaire are then compiled and recapitulated with quantitative analysis methods based on the assessment aspects that have been determined namely the potential possessed by the community, individuals, families or the community that makes them able to prevent, reduce, be prepared, and be able to recover immediately from an emergency activity disaster. This ability was assessed by a questionnaire to find out some capacity building factors including disaster management institutional arrangements at the city/village level, early warning, and disaster risk assessment at the village level; disaster education carried out by the village, efforts to reduce basic risk factors in the village, and village preparedness on all lines. The five aspects of capacity assessment will later be presented in tabular form to be assessed and given a score. Every "yes" answer in the questionnaire is worth one, and each "no" answer is 0 . To know the score of each factor, the question value is multiplied by the weight of the indicator. Factor scores are then added up so that the level of capacity of each village can be classified as Rachmawati [9].

The total score of $0-12$ is the low capacity village category, the overall score of 13-24 is the medium capacity village and the total score.

\section{Results and Discussions}

Mempawah Regency is geographically located in most of the coastal region and on the shores of the South China Sea. So it has the potential to be prone to disasters due to rising sea levels. This geographical location also makes Mempawah Regency has a huge potential in terms of tourism and marine fisheries for its people. Also, the development of settlements along the coast of Mempawah Regency has an impact on the formation of new settlements such as fishing settlements. However, that must be considered with this potential and development; it should also be noted that the risks of disasters that will occur, especially with natural disasters that are not easy to predict. One of the disasters that often occur in Mempawah Regency is the flood and tidal disasters caused by high sea-level rise and the presence of strong wind waves.

Therefore, to anticipate the vulnerability of this disaster, a study was conducted on the level of capacity of disaster risk from the potential aspects of the community, individual, family, or community. This anticipation will make them able to prevent, reduce, be prepared, and be able to recover immediately from an activity disaster emergency. This ability was assessed by a questionnaire to find out some capacity building factors including disaster management institutional arrangements at the city/village level, early 
warning, and disaster risk assessment at the village level; disaster education carried out by the village, efforts to reduce basic risk factors in the village, and village preparedness on all lines.
The factors, indicators, and weight of the capacity assessment that will be presented in the questionnaire are listed in the following table..

Table 1. Factors, Indicators, and Capacity Assessment Quality

\begin{tabular}{|c|c|c|}
\hline Factor & Indicator & Quality \\
\hline \multirow[t]{4}{*}{$\begin{array}{l}\text { Institutional regulation on disaster } \\
\text { management at the local level }\end{array}$} & $\begin{array}{l}\text { Villages have adopted the aspect of disaster risk } \\
\text { reduction in preparing village scale planning } \\
\text { documents }\end{array}$ & 1 \\
\hline & $\begin{array}{c}\text { Formed community groups concerned about } \\
\text { disaster risk reduction }\end{array}$ & 2 \\
\hline & $\begin{array}{c}\text { Villages have formed disaster prepared villages or } \\
\text { are being planned to become disaster prepared } \\
\text { villages }\end{array}$ & 3 \\
\hline & $\begin{array}{c}\text { Government and NGO facilities related to disaster } \\
\text { risk reduction }\end{array}$ & 4 \\
\hline \multirow[t]{4}{*}{$\begin{array}{c}\text { Early warning and disaster risk } \\
\text { assessment }\end{array}$} & $\begin{array}{l}\text { Have minimal district scale disaster risk } \\
\text { assessments known to village officials }\end{array}$ & 1 \\
\hline & Distribution of disaster maps & 2 \\
\hline & $\begin{array}{c}\text { Installation of early warning systems by the } \\
\text { government }\end{array}$ & 3 \\
\hline & $\begin{array}{l}\text { Installation of early warning by organizational } \\
\text { groups or communities }\end{array}$ & 4 \\
\hline \multirow[t]{3}{*}{ Disaster education } & $\begin{array}{c}\text { The community is aware of the threat of flooding } \\
\text { as evidenced by the absence of community } \\
\text { resistance when evacuated }\end{array}$ & 1 \\
\hline & $\begin{array}{l}\text { Has conducted socialization related to flood } \\
\text { disasters on a village scale }\end{array}$ & 2 \\
\hline & $\begin{array}{l}\text { Simulations have been conducted to deal with } \\
\text { floods on a village scale }\end{array}$ & 3 \\
\hline \multirow[t]{3}{*}{ Reduction of basic risk factors } & $\begin{array}{l}\text { The village government collects vulnerable groups } \\
\text { (toddlers, seniors and people with disabilities) }\end{array}$ & 1 \\
\hline & $\begin{array}{l}\text { Strengthening the community's economy in the } \\
\text { form of training and provision of assistance } \\
\text { (excluding Direct Assistance from Buds and } \\
\text { Raskin) }\end{array}$ & 2 \\
\hline & Social action to increase community capacity & 3 \\
\hline \multirow[t]{3}{*}{$\begin{array}{l}\text { Development preparedness on all } \\
\text { lines }\end{array}$} & $\begin{array}{l}\text { The existence of the emergency response } \\
\text { command system and involving village officials }\end{array}$ & 1 \\
\hline & $\begin{array}{l}\text { Having special volunteers for disaster } \\
\text { management }\end{array}$ & 2 \\
\hline & $\begin{array}{c}\text { Volunteers gain access to coordinate with the } \\
\text { district BPBD }\end{array}$ & 3 \\
\hline
\end{tabular}

Source : Rachmawati, 2018 
The following is a table of capacity assessment results in 17 villages in 3 sub-districts in Mempawah District.

Table 2: Capacity Questionnaire Recapitulation

\begin{tabular}{|c|c|c|c|c|c|c|c|c|c|c|c|c|c|c|c|c|c|c|}
\hline \multirow{2}{*}{\multicolumn{2}{|c|}{$\begin{array}{c}\text { Factor } \\
\text { Indicator }\end{array}$}} & \multicolumn{4}{|c|}{ A } & \multicolumn{4}{|c|}{$\mathrm{B}$} & \multicolumn{3}{|c|}{$\mathrm{C}$} & \multicolumn{3}{|c|}{$\mathrm{D}$} & \multicolumn{3}{|c|}{$E$} \\
\hline & & 1 & 2 & 3 & 4 & 1 & 2 & 3 & 4 & 1 & 2 & 3 & 1 & 2 & 3 & 1 & 2 & 3 \\
\hline $\begin{array}{c}\text { Mempawah } \\
\text { Hilir }\end{array}$ & $\begin{array}{l}\text { Desa Kuala } \\
\text { Secapah }\end{array}$ & 1 & 0 & 1 & 0 & 0 & 0 & 1 & 0 & 1 & 1 & 0 & 0 & 0 & 1 & 0 & 0 & 0 \\
\hline & $\begin{array}{l}\text { Desa } \\
\text { Malikian }\end{array}$ & 1 & 0 & 1 & 0 & 0 & 0 & 0 & 0 & 1 & 1 & 0 & 0 & 0 & 1 & 0 & 0 & 0 \\
\hline & $\begin{array}{l}\text { Desa } \\
\text { Penibung }\end{array}$ & 0 & 0 & 1 & 0 & 0 & 0 & 1 & 0 & 1 & 1 & 0 & 0 & 0 & 1 & 0 & 0 & 0 \\
\hline & Desa Pasir & 1 & 0 & 1 & 0 & 1 & 0 & 1 & 0 & 1 & 1 & 0 & 0 & 0 & 1 & 0 & 0 & 0 \\
\hline & $\begin{array}{l}\text { Desa } \\
\text { Sengkubang }\end{array}$ & 1 & 0 & 1 & 0 & 0 & 0 & 1 & 0 & 1 & 1 & 0 & 0 & 0 & 1 & 0 & 0 & 0 \\
\hline $\begin{array}{c}\text { Kecamatan } \\
\text { Siantan }\end{array}$ & $\begin{array}{l}\text { Desa } \\
\text { Jungkat }\end{array}$ & 1 & 0 & 1 & 0 & 0 & 0 & 1 & 0 & 1 & 1 & 0 & 0 & 0 & 1 & 0 & 0 & 0 \\
\hline & $\begin{array}{l}\text { Desa Peniti } \\
\text { Luar }\end{array}$ & 0 & 0 & 1 & 0 & 0 & 0 & 1 & 0 & 1 & 1 & 0 & 0 & 0 & 1 & 0 & 0 & 0 \\
\hline & $\begin{array}{l}\text { Desa Sungai } \\
\text { Nipah }\end{array}$ & 0 & 0 & 0 & 0 & 0 & 0 & 0 & 0 & 1 & 1 & 0 & 0 & 0 & 1 & 0 & 0 & 0 \\
\hline & $\begin{array}{l}\text { Desa Wajok } \\
\text { Hilir }\end{array}$ & 1 & 0 & 0 & 0 & 0 & 0 & 1 & 0 & 1 & 1 & 0 & 0 & 0 & 1 & 0 & 0 & 0 \\
\hline
\end{tabular}




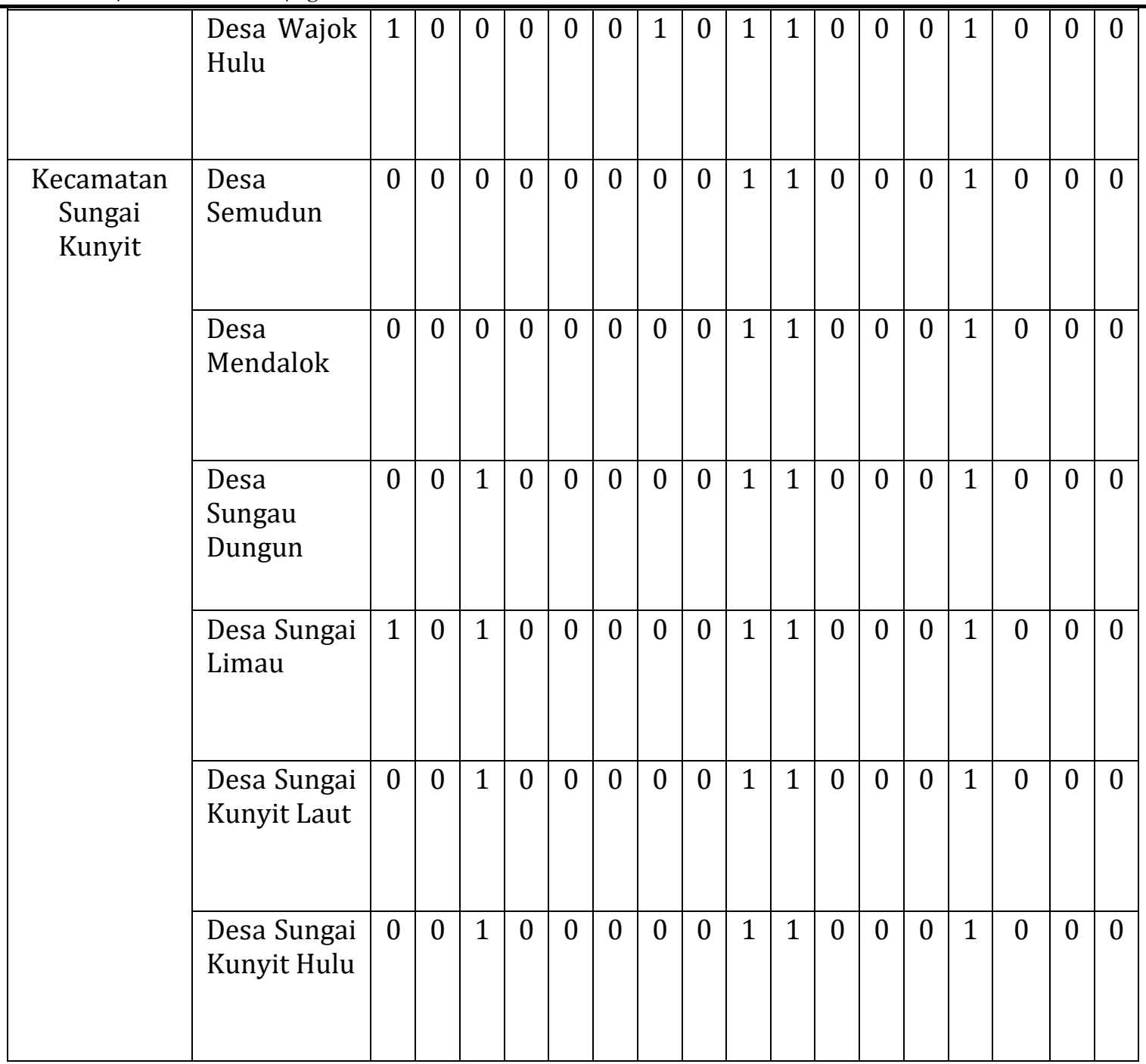

Source: Analysis, 2019; Information: $1=$ Yes; $0=$ No

Table 3. Results of Assessment of Capacity Levels for Disasters

\begin{tabular}{|c|c|c|c|c|c|c|c|}
\hline \multirow[t]{2}{*}{ Village } & \multicolumn{5}{|c|}{ Score Factor } & \multirow{2}{*}{$\begin{array}{l}\text { Score } \\
\text { Total }\end{array}$} & \multirow[t]{2}{*}{ Capacity } \\
\hline & $\mathrm{A}$ & $\mathrm{B}$ & $\mathrm{C}$ & $\mathrm{D}$ & E & & \\
\hline \multicolumn{8}{|c|}{ Sub-districts Mempawah Hilir } \\
\hline Village Kuala Secapah & 4 & 3 & 3 & 3 & 0 & 13 & Medium \\
\hline Village Malikian & 4 & 0 & 3 & 3 & 0 & 10 & Low \\
\hline Village Penibung & 3 & 3 & 3 & 3 & 0 & 12 & Low \\
\hline Village Pasir & 4 & 4 & 3 & 3 & 0 & 14 & Medium \\
\hline Village Sengkubang & 4 & 3 & 3 & 3 & 0 & 13 & Medium \\
\hline \multicolumn{8}{|l|}{ Kecamatan Siantan } \\
\hline Village Jungkat & 4 & 3 & 3 & 3 & 0 & 13 & Medium \\
\hline Village Peniti Luar & 3 & 3 & 3 & 3 & 0 & 12 & Low \\
\hline Village Sungai Nipah & 0 & 0 & 3 & 3 & 0 & 6 & Low \\
\hline Village Wajok Hilir & 1 & 3 & 3 & 3 & 0 & 10 & Low \\
\hline
\end{tabular}




\begin{tabular}{|l|c|c|c|c|c|c|c|c|c|}
\hline Village Wajok Hulu & 1 & 3 & 3 & 3 & 0 & 10 & Low \\
\hline Kecamatan Sungai Kunyit & 0 & 0 & 3 & 3 & 0 & 6 & Low \\
\hline Village Semudun & 0 & 0 & 3 & 3 & 0 & 6 & Low \\
\hline Village Mendalok & 3 & 0 & 3 & 3 & 0 & 9 & Low \\
\hline Village Sungau Dungun & 4 & 0 & 3 & 3 & 0 & 10 & Low \\
\hline Village Sungai Limau & 3 & 0 & 3 & 3 & 0 & 9 & Low \\
\hline Village Sungai Kunyit Laut & 3 & 0 & 3 & 3 & 0 & 9 & Low \\
\hline Village Sungai Kunyit Hulu & 7
\end{tabular}

Source: Analysis, 2019

The total score of $0-12$ is the low capacity village category, the overall score of 13-24 is the medium capacity village, and the total score of $25-38$ is the high capacity village category. From table 2 and table 3 above shows the assessment of the capacity results of all indicators that are part of the assessed. Institutional assessments in villages in Mempawah Hilir Subdistrict, Siantan Subdistrict, and Sungai Kunyit Subdistrict are still very low, especially in indicators that community groups are not yet concerned about disaster risk reduction, and there are no government and NGO facilities related to disaster risk reduction. However, there are several villages namely Penibung Village, Peniti Luar Village, Semudun Village, Mendalok Village, Sungai Dungun Village, Sungai Kunyit Laut Village, and Sungai Kunyit Hulu Village, the village level has not yet adopted regulations on disaster risk reduction aspects in compiling village-scale planning documents so that it will influence the village institutional rules for disaster management for the community. Especially for Semudun Village and Mendalok Village in Sungai Kunyit Subdistrict, they have very low scores for institutional assessments because village level regulations/plans have not adopted the disaster risk reduction aspects.

Early warning and disaster assessment conditions at the village level are still lacking. However, in Kuala Secapah village, Pasir Village, Sengkubang Village, Penibung Village, Peniti Luar Village, Wajok Hilir Village, Wajok Hulu Village, and Jungkat
Village have paid attention to the early warning system implemented by the local community. All villages in the 3 (three) districts do not have a disaster risk map and do not yet have a disaster risk assessment.

In the case of disaster education in all villages, the community has been aware of the threat of danger, and the village officials have given outreach related to flooding in their respective villages. Only simulations have not been done to deal with danger. Even though this simulation is very important, to provide learning for the community in the event of a disaster, things they must do in the situation of a disaster that will come later. In an effort to reduce disaster risk, the government has not collected data on vulnerable groups, and priorities must be evacuated in the event of a disaster. Even so, social action to increase the capacity of the community in dealing with disasters has been carried out by all villages in the Districts in Mempawah Regency with the assistance of relevant institutions, namely the Regional Disaster Management Agency of Mempawah Regency.

The condition of village preparedness in dealing with disaster risk is deficient because the village does not yet have individual volunteers in disaster management. However, when interviews were conducted directly with village officials and villagers, they were willing to become individual volunteers to handle disaster emergencies. So what needs to be done by Mempawah Regency BPBD is to facilitate and empower village communities who are eager to become volunteers in the 
form of training activities and disaster alert empowerment.

\section{Conclusion}

Reviewing all the capacitance factors above, from factor A to factor E, it can be concluded that the capacity level of each village in the Mempawah District is still deficient. This low capacity value is dominated in villages in Sungai Kunyit and Siantan Districts. Villages that have moderate capacity value are Kuala Secapah Village, Pasir Village, Sengkubang Village, and Jungkat Village. Overall, villages in Mempawah sub-district are still low on the early warning factor and disaster risk assessment and preparedness development factors on all lines. And what needs to be considered in most villages is that simulation activity is needed in dealing with the flood situation in their villages. So that the distribution of disaster maps that almost all villages do not have must be made immediately and disseminated to village officials and village communities in all districts in Mempawah Regency.

\section{Acknowledgement}

We would like to thank the Ministry of Research, Technology, and Higher Education for providing research funding assistance in the 2019 Higher Education Flagship Applied Research Scheme.

\section{References}

[1] Badan Penanggulangan Bencana Daerah Pemerintah Propinsi Kalimantan Barat. Rencana Strategis (Renstra) Badan Penanggulangan Bencana Daerah Provinsi Kalimantan Barat 2013-2018 Pontianak Kalimantan Barat: Badan Penanggulangan Bencana Daerah Pemerintah Propinsi Kalimantan Barat; 2013.

[2] Badan Meteorologi, Klimatologi, dan Geofisika. LIPi dan BNPB Menyelenggarakan Seminar Nasional "Penguatan Ketangguhan Berbasis Masyarakat Dalam Mitigasi Bencana Alam dan Perubahan Iklim". Jakarta: http://www.bmkg.go.id/berita/?p=lipi-dan-bnpbmenyelenggarakan-seminar-nasional-penguatanketangguhan-berbasis-masyarakat-dalam-mitigasi-
bencana-alam-dan-perubahan-iklim\&tag=\&lang=ID;

2016.

[3] Buchori, Imam. dkk. Model Kesesuaian Lahan Berbasis Kerawanan Bencana Alam, Uji Coba : Kota Semarang. Jurnal Tata Loka Universitas Diponegoro. 2013 November; Volume 15 ( Nomor 4 pages 293-305)

[4] Hidayat, Arif. Analisis Pengembangan Kawasan Pesisir berbasis Mitigasi Sea Level Rise (KenaikanMukaAir Laut) Studi Kasus Kawasan Kota Lama Makasaar. Jurnal Lingkungan Binaan Indonesia IPLBI. 2012 Juli ; vol 1(No 1).

[5] http://www.kalbariana.web.id/page/467/. Pangan Terancan Karena Perubahan Iklim. Equator-news.com:; 2011.

[6] Koddeng, Baharuddin. Zonasi Kawasan Pesisir Pantai Makassar Berbasis Mitigasi Bencana (Studi Kasus Pantai Barambong-Celebes Convention Centre). In Prosing Hasil Penelitian Fakultas Teknik; Volume 5 : Desember 2011 ISBN: 978-979-127255-0-6; Makassar.

[7] Pratama, Yogi, Abang. Kusnandar, Dadan. Debataraja, Nesyana. Analisis Dampak Kenaikan Muka Air Laut di Kabupaten Kubu Raya dan Kabupaten Mempawah dengan Metode Analytical Hierarchy Process (AHP). Buletin Ilmiah Math. Stat. dan Terapannya (Bimaster). 2017; Vol 6 (No 3): p. 167-176. [8] Presiden Republik Indonesia. Peraturan Pemerintah Republik Indonesia No 64 Tahun 2010 Tentang Mitigasi Bencana di Wilayah Pesisir dan Pulau-Pulau Kecil Jakarta: Menteri Hukum dan Hak Asasi Manusia Republik Indonesia; 27 Agustus 2010.

[9] Rachmawati, Ayu, Turningtyas. Rahmawati, Dwi. Susilo Adi. 2018. Pengurangan Risiko Bencana Berbasis Tata Ruang. Penerbit UB Press.

[10] Smitt, Barry. Wandell, Johanna. 2006. Adaptation, Adaptive Capacity And Vulnerability. Global Environment Change, Vol. 16, Issue 3, August 2006, page 282-292. Elsevier Journal.

[11] Brooks, Nick. Adger, Neil. Kelly, Mick. 2005. The Determinants Of Vulnerability And Adaptive Capacity At The National Level And The Implications For Adaptation. Global Environment Change, Vol. 15, Issue 2, July 2005, page 151-163. Elsevier Journal.

[12] Fuchs, Sven. Birkmann, Jorn. Glade, Thomas. 2012. Vulnerability Assessment In Natural Hazard And Risk Analysis: Current Approaches And Future Challenges. Natural Hazard Journal, Vol. 64, Issue 3, Desember 2012, page 1969-1975. Springer Link.

[13] Birkmann, J. Etc. 2013. Framing Vulnerability, Risk And Societal Responses: The MOVE framework. Natural Hazard Journal, Vol. 67, Issue 2, June 2013, page 193-211. Springer Link. 
. (This page is intentionally left blank) 